\title{
Transfer of Recessive skr Crossability Trait into Well-adapted French Wheat Cultivar Barok through Marker-assisted Backcrossing Method**
}

\author{
A. Bouguennec ${ }^{1 *}$, V.S. Lesage ${ }^{1}$, I.Gateau $^{1}$, P. Sourdille $^{1}$, \\ J. JAHIER ${ }^{2}$ and P. LONNET ${ }^{3}$ \\ ${ }^{1}$ INRA-UCA GDEC, 5 chemin de Beaulieu, F-63000 Clermont-Ferrand, France \\ ${ }^{2}$ INRA IGEPP, Domaine de la Motte au Vicomte BP35327, F-35653 Le Rheu Cedex \\ ${ }^{3}$ GIE TRITICALE, 7 rue Coq-héron, F-75030 Paris cedex 01 \\ (Received 9 April 2018; Accepted 8 May 2018; \\ Communicated by L. Bona)
}

\begin{abstract}
In order to increase genetic diversity in cereals, interspecific or even intergeneric crosses are worthwhile, especially wheat by rye crosses for triticale production. However, these crosses often fail due to inhibiting genes. To overcome this obstacle, crossability trait, present in a few wheat cultivars, can be transferred into other wheat lines of agronomical interest. Nevertheless, this transfer remains tedious through conventional backcrossing methods because it is a recessive trait, which requires selfing generations and complex evaluation by many crosses. Here, we present a marker-assisted backcrossing method to transfer this trait more quickly and easily. We chose to introduce the recessive crossability $s k r$, located on chromosome 5BS and originating from Asian wheat, into Barok, a non-crossable French wheat cultivar, with good agronomic characteristics. Six molecular markers, close to the $\mathrm{Skr}$ locus, were used to check the transfer of the gene at each of the three backcrosses, without selfing generation nor crosses with rye. Finally, we crossed the predicted crossable lines with rye to validate their crossability. We obtained sixteen lines, morphologically similar to Barok, exhibiting high crossability rate $(30 \%)$. The markers were thus efficient to transfer the $s k r$ crossability but they remain too far from the $S k r$ locus to be considered as diagnostic markers. Indeed, genotyping and phenotyping on other wheat cultivars showed some discrepancies. Nevertheless, this opens the way to enhance genetic diversity more easily and to improve traits of agronomic interest in triticale or wheat as well as to study further barriers to intergeneric crosses.
\end{abstract}

Keywords: genetic diversity, intergeneric cross, crossability gene, molecular markers, triticale

Abbreviations: cv: cultivar; BC: Back-Cross; ISBP: Insertion site-based polymorphism; SSR: Simple Sequence Repeat

*Corresponding author; E-mail: annaig.bouguennec@inra.fr

**This article was presented on the 9th International Triticale Symposium, May 23-27, 2016, in Szeged, Hungary. 


\section{Introduction}

In plant breeding, wide hybridization is the first step to introduce alien variation and to transfer desirable traits from wild species into cultivated species. Generally, amphiploids resulting from crosses between wheat and any distantly related species are backcrossed with elite lines to recover agronomical performances. Selection in the backcross progenies may lead to introduction of whole chromosomes in the wheat genome as for addition and substitution lines (Shepherd and Islam 1988), as well as chromosome arms such as 1BL-1RS translocation (Zeller and Hsam 1984) or even smaller fragment of chromosomes carrying introgressed genes. These possibilities have been widely used for small grain cereals breeding for many traits as disease resistance, grain quality, frost or drought resistance (Jiang et al. 1994; Friebe et al. 1996; Schneider et al. 2008). Wide hybridization may also lead to creation of new species through polyploidization, either spontaneously like for durum wheat and later bread wheat (Feldman 2001) or through human action as for triticale (Oettler 2005) and tritordeum (Cubero et al. 1986). In these cases, the whole genomes of both species are retained. New intergeneric crosses are necessary for increasing genetic diversity of these species: triticale, tritordeum and even bread wheat by crossing again durum wheat and Aegilops, i.e. synthetic wheat (Ginkel and Ogbonnaya 2007).

However, interspecific and intergeneric crosses are not straightforward and breeders have to overcome many barriers such as poor crossability and seed setting, no embryo development, no endosperm development requiring in vitro embryo rescue, poor germination of hybrid seeds, necrosis, meiotic instability and sterility. Depending on the objective, only one successful cross (insertion of one gene for example) or in contrast, numerous successful crosses (increase of genetic diversity) may be necessary. Nevertheless, easy success of interspecific or intergeneric crosses is essential and especially in the second case, as for triticale.

Indeed, for triticale, a man-made cereal, no natural genetic resources exists and wheatrye crosses must be made to increase diversity. The success of that intergeneric hybridization depends mainly on the crossability of the wheat genotype used. In 1916, Backhouse showed that this trait is controlled by a Mendelian factor and Lein (1943) described the effects of two genes, $K r l$ and $K r 2$, whose recessive alleles allow crossability. $K r l$ was first located using a telosomic mapping technique on chromosome arms 5BL (Lange and Riley 1973) and later $K r 1$ and $K r 2$ were located on 5BL and 5AL, respectively (Sitch et al. 1985). Two other genes, $K r 3$ and $K r 4$, inhibiting intergeneric crosses, were identified and located on chromosomes 5D (Krolow 1970) and 1A (Zheng et al. 1992) respectively. More recently, a major locus named $S k r$ was identified on chromosome arm 5BS (Tixier et al. 1998). In each case, only recessive alleles allow crossability with a wide range of effect. Most crossable wheat lines have an Asian origin (Zeven 1987) even if some rare European wheat cultivars are crossable. However, Asian wheat cultivars are not well adapted to European growing conditions. This is why introduction of crossability in some European wheat varieties is required. Gay and Bernard (1994) introduced the 5B chromo- 
some from Japanese Fukuhokomugi cultivar, carrying krl allele, into cv Courtot as intervarietal chromosome substitution lines Courtot (5B Fukuhokomugi). Molnár-Láng et al. (1996) used backcross method to introduce crossability ( $k r 1$ and $k r 2)$ in Martonvásári-9 cultivar. Bouguennec $\left(2009,7^{\text {th }}\right.$ International Triticale Symposium, unpublished; Alfares et al. 2009) achieved the same long backcross process, with selfing and testcrosses with rye at each generation, for eleven French wheat cultivars. The crossability source was the intervarietal substitution line Courtot (5B Fukuhokomugi) and also cv Deucendeu, a rare European crossable wheat. Studies in our laboratory (unpublished data) revealed that their crossability was mainly due to $s k r$ allele on 5BS, instead of $k r 1$ on 5BL. We then focused on $S k r$ locus on 5BS chromosome, which was found to have the strongest effect in Chinese Spring $\times$ Courtot progeny and also in lines derived from Fukuhokomugi and Deucendeu. Our laboratory conducted several studies on this $S k r$ locus (Tixier et al. 1998; Lamoureux et al. 2002; Alfares et al. 2009) to find markers as close as possible to this locus.

The aims of this study were (i) to introduce $s k r$ crossability in more recent and welladapted wheat (ii) to test reliability of molecular markers revealed by previous INRA studies to facilitate and shorten introduction of crossability and (iii) to test these markers as diagnostic markers to identify new crossable cultivars in European wheat.

\section{Material and Methods}

\section{Plant material}

In a first experiment, we used two lines as crossable sources: 'Balthazar-crossable' and 'Ornicar-crossable'. Balthazar and Ornicar were two of the eleven French wheat cultivars backcrossed by Courtot (5B Fukuhokomugi). We chose Barok (French wheat cultivar registered in 2008) for its good agronomic characteristics as non-crossable wheat. We tested crossability with three rye cultivars, known to be good pollinators from previous studies: Dankowskie Nowe (old variety), Elego and Dukato (more recent varieties).

In a second experiment, we used 12 other wheat cultivars (from our triticale diversification program based on primary triticale production) to evaluate if our markers could be used as diagnostic markers on more genetically diverse cultivars. These 12 wheat cultivars were: Azzerti, Bergamo, Cellule, Ethic, Fructidor, Grapeli, Kavkaz K4500, Lyrik, M6-synthetic, Nogal, Rubisko and Veranopolis. We crossed them with eight rye cultivars of agronomic interest: Brasetto, Conduct, Dankowskie Nowe, Dukato, Elego, Placido, Marcelo and SU Allawi.

\section{Markers}

According to the previous studies in our laboratory (Alfares et al. 2009), three SSR markers were used in 2012 (cfb306, cfb341 and gwm234) and four closer markers from 2013 to 2015 (TGlc2, cfb341, gene12 and gene13) (Table 1). TGlc2 marker was designed 
Table 1. Characteristics of codominant molecular markers used (designed in our laboratory, except gmw234, Röder et al. 1998)

\begin{tabular}{|c|c|c|c|}
\hline Marker name & $\begin{array}{c}\text { Primer F sequence } \\
\text { Primer R sequence }\end{array}$ & Type & $\begin{array}{c}\text { Genetic distance } \\
\text { from } S k r(\mathrm{~cm})\end{array}$ \\
\hline $\mathrm{cfb} 306$ & $\begin{array}{c}\text { TAAAGCGGATGGGTCTTGTT } \\
\text { ATAAGATTACCTCGGGTGAA }\end{array}$ & SSR & 0.6 \\
\hline $\mathrm{cfb} 341$ & $\begin{array}{c}\text { TAATTAGGGCCTGCTTCTGCT } \\
\text { TTCCTTCATCCAAAGAGACTGG }\end{array}$ & SSR & 0.0 \\
\hline TGlc2 & $\begin{array}{c}\text { TGATTGCTCCACAAAACTGC } \\
\text { GCTGCATCTCTTCCAGTTCC }\end{array}$ & ISBP & 0.0 \\
\hline gene12 & $\begin{array}{c}\text { CCGTCCAGAAATTAACTGTCG } \\
\text { TGAAATTCAGTTGCCACTTC }\end{array}$ & Genomic & 0.0 \\
\hline gene13 & $\begin{array}{c}\text { CTGCTGGTGGACAACGAGACC } \\
\text { GAGGAAGCAAGAATCCGTAGG }\end{array}$ & Genomic & 0.4 \\
\hline gwm234 & $\begin{array}{c}\text { GAGTCCTGATGTGAAGCTGTTG } \\
\text { CTCATTGGGGTGTGTACGTG }\end{array}$ & SSR & 2.2 \\
\hline
\end{tabular}

through ISBP technic (Paux et al. 2010). Gene12 and gene13 markers were designed through synteny with rice (genes Os12g44100-1 and Os12g44090, respectively). All these markers are located close to the $S k r$ locus at the distal end of the short arm of chromosome 5BS. Distances between markers and $S k r$ locus are calculated through recombination rates within the SSD 254-14 heterogeneous inbred family population (unpublished data obtained after Alfares et al. 2009). TGlc2, cfb341 and gene12 markers co-segregate with the $s k r$ crossability phenotype in this population.

\section{Extraction of DNA and PCR}

DNAs from plant leaf sample were obtained by automated DNA extraction on BioSprint96 using BioSprint96 plant kit (Qiagen, Hilden, Germany) in 2012-2013 and on oKtopure using sbeadex Livestock kit in 2014-2015 (LGC Genomics, Middlesex, United Kingdom). PCR reactions for markers were performed using the following conditions: $3 \mu \mathrm{L}$ of DNA $(10 \mathrm{ng} / \mu \mathrm{L})$ were added to $7 \mu \mathrm{L}$ of buffer containing Ampli Taq Gold Master Mix (Applied Biosystems - Life technologies, Courtaboeuf, France) and primers (10 $\mu \mathrm{M}$ for unmarked primer and $1 \mu \mathrm{M}$ for marked primer). The fluorochrome used was VIC. Seven cycles of: $30 \mathrm{~s}$ at $95{ }^{\circ} \mathrm{C}-30 \mathrm{~s}$ at $62^{\circ} \mathrm{C}\left(-1{ }^{\circ} \mathrm{C} /\right.$ cycle, to hitch easily primers to DNA) $-30 \mathrm{~s}$ at $72{ }^{\circ} \mathrm{C}$, were done. They were followed by 30 cycles of: $30 \mathrm{~s}$ at $95^{\circ} \mathrm{C}-$ $30 \mathrm{~s}$ at $55^{\circ} \mathrm{C}-30 \mathrm{~s}$ at $72{ }^{\circ} \mathrm{C}$. At the end, 20 cycles of: $30 \mathrm{~s}$ at $95^{\circ} \mathrm{C}-30 \mathrm{~s}$ at $56^{\circ} \mathrm{C}-30 \mathrm{~s}$ at $72{ }^{\circ} \mathrm{C}$, were done to add oligoM13 and the fluorochrome. All the cycles were performed in Veriti 384 wells thermocyclers. Markers were detected after migration on a 3730 XL DNA analyser (Applied Biosystems) and data were analyzed with Genemapper software V4.0. 


\section{Marker-assisted backcrossing method}

Figure 1 shows the marker-assisted backcrossing method applied. Crossable wheat, carrying $s k r$ (crossable allele of $S k r$ locus), was crossed with a non-crossable well-adapted wheat (carrying $S k r$, non-crossable allele). After each backcross (BC), we selected heterozygous plants by markers to avoid the loss of $s k r$ allele. As half of the plants were expected to be heterozygous, we tested 5 to 7 plants from each previously crossed spike or plant each time in order to have a $97 \%-99 \%$ chance to obtain at least one heterozygous plant from each origin. After $3 \mathrm{BC}$, near $94 \%$ of recurrent wheat were statistically expected to be recovered. Morphological observations controlled the genetic background recovery. The last step consisted in selfing the BC3 F1 (Skr/skr) and selecting crossable homozygous BC3 F2 plants $(s k r / s k r)$ by markers. As a quarter of the plants were expected to be homozygous $s k r / s k r$, we tested around 12 plants from each origin in order to have a $97 \%$ chance to obtain at least one crossable plant for each origin.

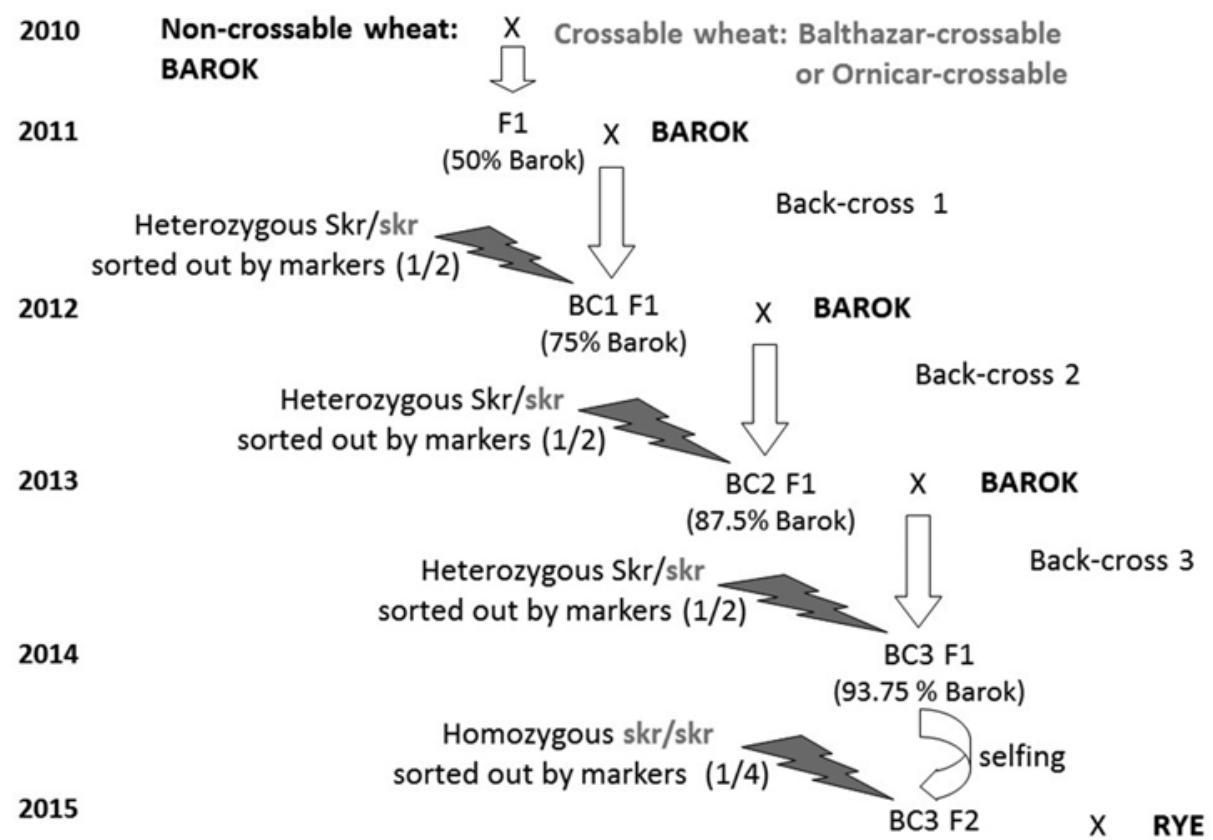

Figure 1. Markers-assisted backcrossing method

Validation by wheat $\times$ rye crosses

In a first experiment, to validate the successful use of these markers for transferring $s k r$, we had to confirm the crossability of the selected lines obtained. Thus, in 2015, we crossed 
the expected crossable plants with three rye cultivars (one spike by cross, three spikes for each plant).

In a second experiment, to test the possibility to use these markers as diagnostic markers, we genotyped 12 other wheat cultivars (from our triticale diversification program based on primary triticale production) with our four markers as previously and crossed them with eight rye cultivars (recent hybrid and population types). For each wheat female, around 375 (300 to 470) florets were emasculated.

We carried out all crosses in glasshouse: emasculation of all florets of spike after elimination of smaller ones from top and bottom, and pollination with rye 2 or 3 days later.

\section{Results}

At each step of the backcross procedure, we were able to find heterozygous plants and several were used to follow the process. Table 2 shows the results obtained for the last step on 79 BC3 F2. Percentages observed (Table 3) were very close to expected ones (25\% Skr/Skr, 50\% Skr/skr and 25\% skr/skr). We obtained thus 19 hypothetical crossable plants (but one died). Except two plants with slightly more compact spikes (13BB4-2-1-7 and 13BB4-2-1-8), all other plants were morphologically very similar to Barok recurrent parent. Table 4 presents the results for the crosses of these 18 plants with 3 rye cultivars (except 3 plants evaluated with 2 rye cultivars only). The mean crossability for the 18 plants was $31.0 \%$. All plants reached at least $12.9 \%$ of crossability (mean for crosses of this plant with three rye cultivars). The highest one (13BB8-2-1-1) reached $57.4 \%$. Only 7 spikes out of 51 showed poor seed setting (less than 10\%) but it was never more than

Table 2. PCR fragment size for the four markers on crossable and non-crossable lines.

\begin{tabular}{|c|c|c|c|c|c|c|c|c|c|c|c|}
\hline \multirow{3}{*}{$\begin{array}{l}\text { Genotype } \\
\text { Barok }\end{array}$} & \multirow{3}{*}{\begin{tabular}{l}
\multicolumn{1}{c}{ Diagnostic } \\
(Non-crossable \\
check)
\end{tabular}} & \multicolumn{10}{|c|}{ Markers } \\
\hline & & \multicolumn{3}{|c|}{ TGIc2 } & \multicolumn{2}{|c|}{ cfb341 } & \multicolumn{2}{|c|}{ gene12 } & \multicolumn{3}{|c|}{ gene13 } \\
\hline & & 270 & 279 & & 163 & & 342 & & 419 & 451 & \\
\hline $\begin{array}{l}\text { Balthazar- } \\
\text { crossable }\end{array}$ & $\begin{array}{l}\text { (Crossable } \\
\text { check) }\end{array}$ & 270 & & 291 & & 176 & & 391 & 419 & & 456 \\
\hline $\begin{array}{l}\text { Ornicar- } \\
\text { crossable }\end{array}$ & $\begin{array}{l}\text { (Crossable } \\
\text { check) }\end{array}$ & 270 & & 291 & & 176 & & 391 & 419 & & 456 \\
\hline $\begin{array}{l}\text { BC3 F2 } \\
\text { lines } \\
\text { homozygous }\end{array}$ & Crossable & 270 & & 291 & & 176 & & 391 & 419 & & 456 \\
\hline $\begin{array}{l}\text { BC3 F2 } \\
\text { lines } \\
\text { Heterozygous }\end{array}$ & Non-crossable & 270 & 279 & 291 & 163 & 176 & 342 & 391 & 419 & 451 & 546 \\
\hline $\begin{array}{l}\text { BC3 F2 } \\
\text { lines } \\
\text { homozygous }\end{array}$ & Non-crossable & 270 & 279 & & 163 & & 342 & & 419 & 451 & \\
\hline
\end{tabular}

In bold: haplotype of crossable type 
610 BouguenNEC et al.: Transfer of Recessive $s k r$ Crossability Trait into Well-adapted French Wheat

Table 3. Distribution of the 79 BC3 F2 according to molecular markers

\begin{tabular}{|l|c|c|c|}
\hline \multicolumn{1}{|c|}{ Genotype supposed according to markers } & Number of lines & $\begin{array}{c}\text { Percentage } \\
\text { observed }\end{array}$ & $\begin{array}{c}\text { Percentage } \\
\text { expected }\end{array}$ \\
\hline Skr-Skr (homozygous, non-crossable) & 20 & 25.3 & 25 \\
\hline Skr-skr (heterozygous, non-crossable) & 40 & 50.6 & 50 \\
\hline skr-skr (homozygous, crossable) & 19 & 24.1 & 25 \\
\hline
\end{tabular}

Table 4. Crossability of 18 lines obtained with 3 rye cultivars

\begin{tabular}{|c|c|c|c|c|c|}
\hline \multirow{3}{*}{ Crossability source } & \multirow{3}{*}{$\begin{array}{c}\text { Barok-crossable lines } \\
\text { female }\end{array}$} & \multicolumn{4}{|c|}{ Crossability (number of seeds/number of emasculated florets) } \\
\hline & & \multicolumn{3}{|c|}{ Rye male } & \multirow{2}{*}{$\begin{array}{c}\text { Mean } \\
\text { (in percent }\end{array}$} \\
\hline & & D. Nowe & Dukato & Elego & \\
\hline \multirow{5}{*}{ Ornicar-crossable } & $13 \mathrm{BB} 1-2-1-3$ & $11 / 32$ & $12 / 36$ & $\underline{1 / 34}$ & 23.5 \\
\hline & 13BB1-2-2-4 & $18 / 42$ & $6 / 40$ & $13 / 42$ & 29.8 \\
\hline & 13BB2-3-2-13 & $4 / 35$ & $\underline{0 / 40}$ & $15 / 38$ & 16.8 \\
\hline & $13 B B 3-2-1-4$ & $24 / 40$ & $2 / 34$ & $19 / 37$ & 40.5 \\
\hline & 13BB3-2-1-9 & $\underline{0 / 40}$ & $9 / 31$ & $9 / 36$ & 16.8 \\
\hline \multirow{13}{*}{ Balthazar-crossable } & 13BB4-2-1-2 & $8 / 38$ & $4 / 38$ & $9 / 38$ & 18.4 \\
\hline & $13 B B 4-2-1-7$ & $13 / 39$ & $18 / 38$ & - & (40.3) \\
\hline & $13 B B 4-2-1-8$ & $17 / 40$ & $13 / 40$ & - & (37.5) \\
\hline & $13 B B 4-2-1-9$ & $8 / 41$ & 9/39 & $5 / 38$ & 18.6 \\
\hline & 13BB6-2-1-5 & $26 / 40$ & $\underline{0 / 40}$ & $6 / 38$ & 27.1 \\
\hline & $13 B B 7-2-1-2$ & $23 / 38$ & $6 / 37$ & $7 / 38$ & 31.9 \\
\hline & 13BB8-2-1-1 & $30 / 38$ & $9 / 38$ & $27 / 39$ & 57.4 \\
\hline & 13BВ9-2-1-3 & $8 / 42$ & $5 / 35$ & $5 / 34$ & 16.2 \\
\hline & 13BB9-2-1-5 & $25 / 37$ & $\underline{3 / 38}$ & - & (37.3) \\
\hline & $13 \mathrm{BB} 10-2-1-3$ & $17 / 40$ & $17 / 40$ & $16 / 37$ & 42.7 \\
\hline & 13BB10-2-1-5 & $23 / 38$ & $13 / 38$ & $6 / 32$ & 38.9 \\
\hline & 13BB11-2-1-1 & $22 / 43$ & $24 / 39$ & $23 / 42$ & 55.7 \\
\hline & 13BB11-2-1-3 & $8 / 42$ & $6 / 37$ & $\underline{1 / 38}$ & 12.9 \\
\hline \multicolumn{2}{|l|}{ Mean* } & 39.1 & 21.7 & 28.3 & 29.8 \\
\hline
\end{tabular}

Bold: high or rather high crossability $(>10 \%)$. Underline: poor crossability on one spike $(<10 \%)$.

In brakets: plant mean on 2 spikes. *: without the three only partially evaluated plants 
one spike per plant and this could be considered as an occasional failure. One spike gave up to $79.0 \%$ of seeds (13BB8-2-1-1 $\times$ Dankowskie Nowe). All these 18 plants could thus be considered as crossable. Crosses with Dankowskie Nowe gave significantly higher seed set rates on 15 plants $(39.1 \%)$ than with Elego $(28.3 \%)$ or Dukato $(21.7 \%)$. Crossability of the plants selected by markers was thus confirmed and this validated the utilization of these markers to follow the transfer of $s k r$. Moreover, we obtained 285, 156 and 162 seeds from crosses between Barok-crossable and Dankowskie Nowe, Dukato and Elego respectively. These seeds will gave octoploid primary triticale plants, which will be integrated in our triticale diversification program to produce new genitors.

For the second experiment, aiming to evaluating markers as diagnostic markers on 12 wheat cultivars, results (Table 5) showed that five cultivars had the same haplotype as the crossable lines ('Ornicar-crossable' and 'Balthazar-crossable') for at least three markers out of four. Two wheat cultivars (Cellule and M6-Synthetic) were different for gene13 marker, the most distant from $S k r$ locus. However, these wheat cultivars showed a poor crossability (Table 6), except M6-Synthetic. Azzerti and Kavkaz-K4500 also gave occasionally more seeds (around 8.5\%) than expected for non-crossable wheat. However, it was not enough to consider them as fully crossable.

Table 5. PCR fragment size for four markers on 12 wheat cultivars and putative crossability

\begin{tabular}{|c|c|c|c|c|c|c|c|c|c|c|c|}
\hline \multirow{3}{*}{$\begin{array}{l}\text { Genotype } \\
\text { Barok }\end{array}$} & \multicolumn{10}{|c|}{ Markers } & \multirow{3}{*}{$\begin{array}{l}\text { Diagnostic } \\
\begin{array}{l}\text { Non-crossable } \\
\text { (check) }\end{array} \\
\end{array}$} \\
\hline & \multicolumn{3}{|c|}{ TGlc2 } & \multicolumn{2}{|c|}{$\mathrm{cfb} 341$} & \multicolumn{2}{|c|}{ gene12 } & \multicolumn{3}{|c|}{ gene13 } & \\
\hline & 270 & 279 & & 163 & & 342 & & 419 & 451 & & \\
\hline Bergamo & 270 & 279 & & 163 & & 342 & & 419 & 451 & & Non-crossable \\
\hline Ethic & 270 & 279 & & 163 & & 342 & & 419 & 451 & & Non-crossable \\
\hline Fructidor & 270 & 279 & & 163 & & 342 & & 419 & 451 & & Non-crossable \\
\hline Grapeli & 270 & 279 & & 163 & & 342 & & 419 & 451 & & Non-crossable \\
\hline Lyrik & 270 & 279 & & 163 & & 342 & & 419 & 451 & & Non-crossable \\
\hline Nogal & 270 & 279 & & 163 & & 342 & & 419 & 451 & & Non-crossable \\
\hline Rubisko & 270 & 279 & & 163 & & 342 & & 419 & 451 & & Non-crossable \\
\hline $\begin{array}{l}\text { Balthazar- } \\
\text { crossable }\end{array}$ & 270 & & 291 & & 176 & & 391 & 419 & & 456 & Crossable (check)* \\
\hline $\begin{array}{l}\text { Ornicar- } \\
\text { crossable }\end{array}$ & 270 & & 291 & & 176 & & 391 & 419 & & 456 & Crossable (check)* \\
\hline Azzerti & 270 & & 291 & & 176 & & 391 & 419 & & 456 & Crossable \# \\
\hline Kavkaz K4500 & 270 & & 291 & & 176 & & 391 & 419 & & 456 & Crossable \# \\
\hline Veranopolis & 270 & & 291 & & 176 & & 391 & 419 & & 456 & Crossable \# \\
\hline M6-synthetic & 270 & & 291 & & 176 & & 391 & & & 456 & Crossable?* \\
\hline Cellule & 270 & & 291 & & 176 & & 391 & 419 & $\underline{451}$ & & Crossable?\# \\
\hline
\end{tabular}

*Also phenotyped crossable. \#But phenotyped non crossable. Underline: discrepancy for gene13. 
612 BouguenNEC et al.: Transfer of Recessive $s k r$ Crossability Trait into Well-adapted French Wheat

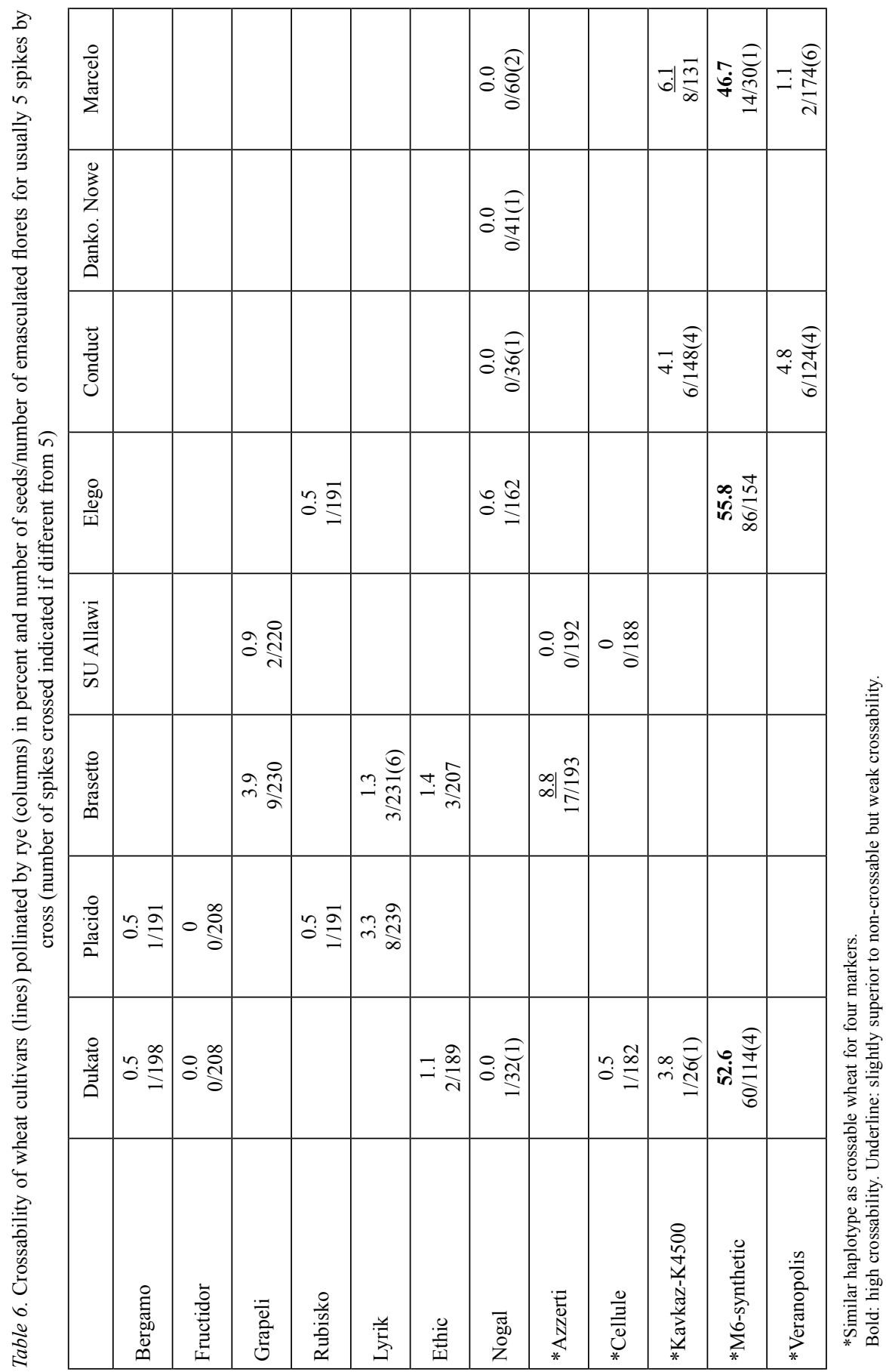

Cereal Research Communications 46, 2018 


\section{Discussion}

By use of molecular markers, we succeeded in transferring the crossability trait $(s k r)$ in Barok French cultivar more quickly and easily than without markers. This was achieved in 5 years for a $93.75 \%$ theoretical genetic background recovery, without time-consuming testcrosses with rye. Obtaining the same result without assistance of markers would have taken 8 years and would have needed a much more heavy and time-consuming work. We could also consider that two BC are sufficient for the aim of diversification of triticale. Then, 4 years after the F1 cross would be enough to obtain useful crossable lines, or even less if we combine the method with speed breeding. This set of $S k r$ markers is efficient for Marker-assisted Selection. However, these markers seem to be unable to predict crossability of a wheat cultivar, as there are some discrepancies between haplotype and crossability trait (see Tables 5 and 6: Azzerti, Cellule, Veranopolis, Kavkaz-K4500). These markers are probably not close enough to the gene to be diagnostic markers, even if they are close enough to follow an introgressed fragment encompassing the $s k r$ locus in polymorphic non-crossable lines. Thus, closer markers for $S k r$ crossability are still necessary.

To evaluate the improvement of crossability in Barok genetic background by this transfer of $s k r$, we could use former results on Barok and lines 'Balthazar-crossable' and 'Ornicar-crossable'. Crosses performed in 2010 (data not shown), in the same conditions, showed a very poor crossability for Barok: a mean of only 1.4\% (from 0 to $3 \%$ ) for crosses with four rye cultivars (Carotop, Guttino, Palazzo and Kapitän) with 9 spikes for each crosses (1430 emasculated florets in total). The same year, with the same rye cultivars but only 2 to 4 spikes for each cross, 'Balthazar-crossable' and 'Ornicar-crossable' showed high crossability, respectively, means of $67 \%$ (from $53 \%$ to $84 \%$ ) and $37 \%$ (from $32 \%$ to $67 \%$ and an occasional failure with cv Guttino). 'Barok-crossable' lines reached a much higher crossability (mean of $30 \%$, from 12.9 to $57.4 \%$ ) than Barok, allowing easy crosses. However, it seems to be lower than crossability reached by 'Balthazar-crossable' and 'Ornicar-crossable'.

This study focuses on wheat crossability provided by $S k r$ locus. However, other genes have also an effect on crossability as $K r 1, K r 2$. The 18 BC3 F2 plants selected with the same markers were all crossable but with a high variability of crossability (from 12.9 to $57.4 \%$ ). The low number of spikes that could be crossed on each plant (three spikes) could explain the variability of results but the possible interaction with other crossability genes may also contribute. Indeed, $K r l$ is probably in disjunction in these lines as it was present on 5B Fukuhokomugi chromosome, the initial source of crossability used. In contrast, during the previous transfers of crossability into Ornicar and Balthazar, without markers, $k r l$ was transferred probably systematically with $s k r$ as the selection of F2 plants was done through wheat by rye crosses and the most crossable plants were always chosen. 'Ornicar-crossable' and 'Balthazar-crossable' are thus probably carrying $s k r / s k r$ and $k r 1 / k r 1$.

Moreover, as shown by Taira et al. (1978) and Oettler (1982), rye genes also may have an effect on crossability. For this reason, three open-pollinated rye cultivars, being known to be rather good pollinators, were used to test the selected plants. Even if crossability 
was high enough to consider these plants as crossable, Dankowskie Nowe gave better results than Dukato and Elego. This confirmed also the effect of rye on this trait.

\section{Conclusion}

In this study, we showed the suitability of markers designed on the wheat Skr locus to speed up the transfer of the crossability recessive trait into agronomic varieties. Now, this crossability trait could be easily transferred in some other wheat cultivars of interest. Using the lines obtained, we are now able to produce numerous primary triticales, taking into account larger rye diversity. These lines may also facilitate intergeneric crosses with other species. This opens the way to improve more extensively genetic diversity and thus traits of agronomic interest in triticale and wheat.

Finally, being able to overcome one of the first hybridization barrier may also allow us to study further barriers occurring in intergeneric crosses within Triticeae, as lack of embryo viability for example. The lines obtained could provide useful genetic material from diverse origins for these studies.

\section{Acknowledgements}

The research was partly supported by GIE TRITICALE (RAGT R2n, Florimond-Desprez, Agri-Obtentions, Lemaire-Deffontaines). Many thanks to breeders implicated in this program for a long time: Jean-Paul Le Goff, Eric Delaleau, Christophe Jeudi and Frédéric Fantin. Research of markers derives from physical mapping and BACs sequencing of the 5BS wheat chromosome performed in collaboration between INRA ClermontFerrand and CNRGV Toulouse. We are grateful to Bouzid Charef for assessing 5B-specificity of markers.

Gentyane High-throughput sequencing \& genotyping platform is gratefully acknowledged for access to technology and help.

\section{References}

Alfares, W., Bouguennec, A., Balfourier, F., Gay, G., Berges, H., Vautrin, S., Sourdille, P., Bernard, M., Feuillet, C. 2009. Fine mapping and marker development for the crossability gene $S k r$ on chromosome 5BS of hexaploid wheat (Triticum aestivum L.). Genetics 183(2):469-481.

Backhouse, W.O. 1916. A note on the inheritance of crossability. J. Genet. 6(2):91-94.

Cubero, J.I., Martín, A., Millán, T., Gómez-Cabrera, A., de Haro, A. 1986. Tritordeum - a new alloploid of potential importance as a protein source crop. Crop Science 26(6):1186-1190.

Feldman, M. 2001. In The World Wheat Book. A history of wheat breeding (In: eds Bonjean A.P. \& Angus W.J.) pp. 3-56 (Tec. \& Doc. Editions, London).

Friebe B., Jiang J., Raupp W.J., McIntosh, R.A., Gill, B.S. 1996. Characterization of wheat-alien translocations conferring resistance to diseases and pests: current status. Euphytica 91:59-87.

Gay, G., Bernard, M. 1994. Production of intervarietal substitution lines with improved interspecific crossability in the wheat cv Courtot. Agronomie 14:27-32.

Ginkel, M. van, Ogbonnaya, F. 2007. Novel genetic diversity from synthetic wheats in breeding cultivars for changing production conditions. Field Crops Research 104(1/3):86-94 
Jiang, J.M., Friebe, B., Gill, B.S. 1994. Recent advances in alien gene-transfer in wheat. Euphytica 73:199-212.

Krolow, K.D. 1970. Untersuchtungen über die Kreuzbarkeit zwischen Weizen und Roggen. (Investigations on compatibility between. wheat and rye). Z. Planzenzüchtg. 64:44-72.

Lamoureux, D., Boeuf, C., Regad, F., Garsmeur, O., Charmet, G., Sourdille, P., Lagoda, P., Bernard, M. 2002. Comparative mapping of the wheat $5 \mathrm{~B}$ short chromosome arm distal region with rice, relative to a crossability locus. Theor. Appl. Genet. 105:759-765.

Lange, W., Riley, R. 1973. Position on chromosome 5B of wheat of locus determining crossability with rye. Gentical Research 22(2):143-153.

Lein, A. 1943. Die genetische Grundlage der Kreuzbarkeit zwischen Weizen und Roggen. (The genetical basis of the crossability between wheat and rye). Z. Indukt. Abstamm. Vererb. Lehre 81:28-59.

Molnár-Láng, M., Linc, G., Sutka, J., 1996. Transfer of the recessive crossability allele $k r 1$ from Chinese Spring into the winter wheat variety Martonvásári 9. Euphytica 90: 301-305.

Oettler, G. 1982. Effect of parental genotype on crossability and response to colchicine treatment in wheat-rye hybrids. Z. Planzenzüchtg. 88(4):322-330.

Oettler, G. 2005. The fortune of a botanical curiosity - Triticale: past, present and future. J. Agric. Sci. 143:329346.

Paux, E., Faure, S., Choulet, F., Roger, D., Gauthier, V., Martinant, J.-P., Sourdille, P., Balfourier, F., Le Paslier, M.-C., Chauveau, A., Cakir, M., Gandon, B., Feuillet, C. 2010. Insertion site-based polymorphism markers open new perspectives for genome saturation and marker-assisted selection in wheat. Plant Biotechnology Journal, 8: 196-210.Schneider, A., Molnar, I., Molnar-Lang, M. 2008. Utilisation of Aegilops (goatgrass) species to widen the genetic diversity of cultivated wheat. Euphytica 163:1-19.

Röder, M.S., Korzun, V., Wendehake, K., Plaschke, J., Tixier, M.H., Leroy, P., Ganal, M.W. 1998. A microsatellite map of wheat. Genetics 149(4):2007-2023

Schneider, A., Molnar, I., Molnar-Lang, M. 2008. Utilisation of Aegilops (goatgrass) species to widen the genetic diversity of cultivated wheat. Euphytica 163:1-19.

Shepherd, K.W., Islam, A.K.M.R. 1988. Fourth compendium of wheat-alien chromosome lines. pp. $1373-1395$. In: T.E. Miller \& R.M.D. Koebner (Eds). Proc. 7th Int. Wheat Genet. Symp., Cambridge, England.

Sitch, L.A., Snape, J.W., Firman, S.J. 1985. Intrachromosomal mapping of crossability genes in wheat (Triticum aestivum). Theor. Appl. Genet. 70:309-314.

Taira, T., Lelley, T., Larter, E.N. 1978. Influence of parental rye on development of embryos and endosperm of wheat-rye hybrids. Can. J. of Botany 56(4):386-390.

Tixier, M.H., Sourdille, P., Charmet, G., Gay, G., Jaby, C., Cadalen, T., Bernard, S., Nicolas, P., Bernard, M. 1998. Detection of QTLs for crossability in wheat using a doubled haploid population. Theor. Appl. Genet. 97:1076-1082.

Zeller, F.J., Hsam, S.L.K. 1984. Broadening the genetic variability of cultivated wheat by utilizing rye chromatin. In S. Sakamoto (ed.), Proc. 6th Int. Wheat Genet. Symp., Kyoto, Japan, 28 Nov.-3 Dec. 1983. Plant Germplasm Int., Kyoto University, Kyoto, Japan. pp. 161-173.

Zeven, A.C. 1987. Crossability percentages of some 1400 bread wheat varieties and lines with rye. Euphytica 36:299-319.

Zheng, Y.L., Luo, M.C., Yen, C., Yang, J.L. 1992. Chromosome location of a new crossability gene in common wheat. Wheat Inf. Service 75:36-40. 